\title{
PENERAPAN MODEL PEMBELAJARAN APTITUDE TREATMENT INTERACTION (ATI) UNTUK MENINGKATKAN H ASIL BELAJAR SISWA GEOGRA FI KELAS X IIS 2 SMA NEGERI 8 KENDARI PADA MATERI POKOK DINAMIKA ATMOSFER DAN DAMPAKNYA TERHADAP KEHIDUPAN
}

\author{
Sahara $^{1}$, La Harudu ${ }^{2}$, La Ode Nursalam ${ }^{3}$ \\ ${ }^{1}$ Program Studi Pendidikan Geografi \\ Universitas Halu Oleo \\ Email: saharageografi1010@gmail.com \\ ${ }^{2}$ Program Studi Pendidikan Geografi \\ Universitas Halu Oleo \\ Email: laharudu@uho.ac.id \\ ${ }^{3}$ Program Studi Pendidikan Geografi \\ Universitas Halu Oleo \\ Email: laodenursalam@gmail.com
}

\section{ABSTRACT}

SMA Negeri 8 Kendari is on e of the schools in the city of Kendari which is the object of research researchers because students ' learning results are still low, when before taki ng remedial to reach the value of the KKM. The purpose of this research is: (1) to describe the learning activities of the X-grade students of IIS 2 SMA Negeri 8 Kendari taught by the ATI learning model; (2) to describe teaching activities of teachers teaching by applying the ATI learning mod el; (3) To find out the increase in geography of the $X$-grade students of IIS 2 SMA Negeri 8 Ke ndari taught using ATI learning models. The data in this study is qualitative and quantitative data ob tained from observation sheets and study results tests. Based on the data analysis results obtained th at: (1) Student learning activities by implementing the ATI learning model on cycle I of 2.45 which belongs to the category enough and in cycle II inc reased to 3.3 in good category; (2) Teacher teaching activities by implementing an ATI learnin g model at Cycle I with an average score of 2.58 including sufficient categories and in the II cycl e experienced an increase of 3.4 belongs to the good category; and (3) there was an increase in the outcomes of the geography of the X-grade IIS 2 SMA Negeri 8 Kendari from cycle I to cycle II. In the I cycle of the lowest value of 50, the highest value is 90 , the average value of 69.40 and the satisfa ction of the study was 60\%. As for the II cycle of the lowest value of 55 ,

the highest value is 95, the a verage value of 77.20 with the submission of stu dy was $80 \%$ or there are 20 out of 25 total students e arning a value of $\geq 70$ according to the geogra phical KKM specified in SMA Negeri 8 Kendari.

Keywords: Learning Model, Teacher, Student, Process, Outcomes 


\begin{abstract}
ABSTRAK
SMA Negeri 8 Kendari merupakan salah satu sekolah di Kota Kendari yang menjadi objek penelitian peneliti karena hasil belajar siswa yang masih rendah, ketika sebelum mengikuti remedial untuk mencapai nilai KKM. Tujuan penelitian ini adalah: (1) untuk mendeskripsikan aktivitas belajar siswa kelas X IIS 2 SMA Negeri 8 Kendari yang diajar dengan model pembelajaran ATI; (2) untuk mendeskripsikan aktivitas mengajar guru yang mengajar dengan menerapkan model pembelajaran ATI; (3) untuk mengetahui peningkatan hasil belajar geografi siswa kelas X IIS 2 SMA Negeri 8 Kendari yang diajar dengan menggunakan model pembelajaran ATI. Data dalam penelitian ini adalah data kualitatif dan kuantitatif yang diperoleh dari lembar observasi dan tes hasil belajar. Berdasarkan hasil analisis data diperoleh bahwa: (1) aktivitas belajar siswa dengan menerapkan model pembelajaran ATI pada siklus I sebesar 2,45 dan termasuk pada kategori cukup, selanjutnya pada siklus II meningkat menjadi 3,3 dalam kategori baik; (2) aktivitas mengajar guru dengan menerapkan model pembelajaran ATI pada siklus I dengan rata-rata skor 2,58 termasuk kategori cukup dan pada siklus II mengalami peningkatan yaitu 3,4 termasuk dalam kategori baik; dan (3) terjadi peningkatan hasil belajar geografi siswa kelas X IIS 2 SMA Negeri 8 Kendari dari siklus I ke siklus II. Pada siklus I yaitu diperoleh nilai terendah 50, nilai tertinggi 90, nilai rata-rata 69,40 serta ketuntasan belajar sebesar $60 \%$. Sedangkan pada siklus II nilai terendah 55, nilai tertinggi 95, nilai rata-rata sebesar 77,20 dengan ketuntasan belajar $80 \%$ atau terdapat 20 dari 25 jumlah keseluruhan siswa memperoleh nilai $\geq 70$ sesuai KKM geografi yang ditentukan di SMA Negeri 8 Kendari.
\end{abstract}

Kata Kunci: Model Pembelajaran Aptitude Treatmen Interaction; Aktifitas Mengajar Guru; Aktifitas Belajar Siswa; Hasil Belajar Siswa

\section{PENDAHULUAN}

Proses belajar merupakan proses yang unik dan kompleks. Setiap manusia mempunyai cara yang khas untuk mengusahakan proses belajar terjadi dalam dirinya. Individu yang berbeda dapat melakukan proses belajar dengan kemampuan yang berbeda dalam aspek kognitif, afektif dan psikomotorik (Purwanto, 2011).

Pembelajaran konvensional belum peduli atau belum mampu mengapresiasi serta mengakomodasi perbedaan-perbedaan individual peserta didik. Guru memberikan pelayanan yang sama untuk semua peserta didik, baik yang memiliki kemampuan tinggi, sedang, dan rendah, sehingga layanan pembelajaran belum sesuai dengan tinggkat kemampuan masing-masing peserta didik. Peserta didik yang lambat selalu saja tertinggal dari kelompok sedang. Sementara peserta didik yang cepat belum mendapat layanan yang optimal dalam pembelajaran (Wiwit Candra Pertiwi, 2017). Sehingga proses pembelajaran tersebut mengakibatkan terjadinya dua kemungkinan berbeda. Pertama, jika guru melanjutkan kemateri selanjutnya tanpa memperhatikan kelompok peserta didik berkemampuan sedang dan rendah, maka tentu saja kelompok peserta didik berkemampuan rendah akan semakin jauh tertinggal dan motivasi belajar mereka akan semakin berkurang. Sebaliknya jika guru tidak melanjutkan ke materi berikutnya dan tetap mengulang materi sebelumnya, maka kelompok peserta didik yang berkemampuan tinggi akan merasa bosan dan jenuh karena mereka harus mengulangi sesuatu yang sudah mereka kuasai. Hal ini juga dapat mempengaruhi motivasi belajar mereka, sedangkan motivasi belajar sangat berpengaruh terhadap keberhasilan peserta didik dalam suatu mata pelajaran (Ismayani, 2011).

Hasil observasi di kelas X IIS 2 SMA Negeri 8 Kendari, diperoleh bahwa setiap peserta didik memiliki perbedaan individu, terutama perbedaan dalam kemampuan (aptitude) akademiknya, dijumpai dalam masing-masing kelas adanya peserta didik yang memiliki perbedaan kemampuan (aptitude) yakni ada peserta didik yang memiliki kemampuan (aptitude) tinggi, sedang dan rendah. Informasi lain yang diperoleh dari observasi yaitu pada proses pembelajaran yang dilakukan di kelas X IIS 2, model yang paling sering digunakan di sekolah adalah pembelajaran yang bersifat konvensional.

Informasi yang diperoleh juga dari hasil wawancara langsung kepada guru geografinya yaitu peserta didik sulit menyelesaikan soal perhitungan pada materi geografi yang berkaitan dengan perhitungan khususnya pada sub pokok materi unsur-unsur cuaca dan ikim pada pokok materi dinamika atmosfer. Akibatnya nilai ratarata ulangan harian peserta didik rendah pada tahun ajaran 2017/2018 ketika sebelum mengikuti remedial untuk mencapai nilai KKM di SMA Negeri 8 Kendari yaitu sebesar 70 . Berdasarkan hal ini, guru dan peneliti melihat perlu adanya penyesuaian antara proses belajar 
dengan tingkat kemampuan yang dimiliki peserta didik, sehingga diharapkan adanya peningkatan hasil belajar pada pelajaran geografi khususnya untuk pokok materi dinamika atmosfer dan hubungannya dalam kehidupan.

Pemilihan model pembelajaran ATI, selain memperhatikan ciri-ciri siswa yang telah diungkapkan sebelumnya, juga didasari anggapan bahwa siswa berkemampuan tinggi akan lebih baik belajar dengan cara mereka sendiri yang terfokus langsung pada penguasaan tujuan pembelajaran. Tujuan dari strategi pembelajaran ini agar kelompok kemampuan tinggi dapat menemukan suatu gagasan sendiri, melatih peserta didik untuk mendiagnosis dirinya sendiri, dan merencanakan perbaikan atas kerjanya sendiri. Beberapa kelebihan model pembelajaran ATI, yaitu: (1) memungkinkan siswa dapat maju menurut kemampuannya masing-masing secara penuh dan tepat, menumbuhkan hubungan pribadi yang menyenangkan antara guru dan siswa; (2) mengurangi hambatan dan mencegah eliminasi terhadap para siswa yang tergolong lamban; (3) adanya kesesuaian antara kemampuan siswa dan cara belajarnya; dan (4) dapat meningkatkan motivasi dan keaktifan siswa dalam proses pembelajaran, sehingga pada akhirnya dapat meningkatkan pemahamannya (Nurdin, 2005; Sriyampriyati, dkk., 2011).

Namun disisi lain metode pembelajaran Aptitude Treatment Interaction (ATI) juga memiliki beberapa kekurangan diantaranya yaitu: (1) membeda-bedakan kemampuan siswa yang bisa membuat siswa merasa kurang adil; (2) membutuhkan waktu yang lama bagi siswa sehingga kurikulum bisa tidak terpenuhi; dan (3) membutuhkan waktu yang lebih lama sehingga pada umumnya guru tidak mau menggunakan model pembelajaran Aptitude Treatment Interaction (ATI) (Hermawan, 2013).

\section{METODE PENELITIAN \\ Jenis Penelitian}

Jenis penelitian ini adalah penelitian tindakan kelas. Dimana PTK ini merupakan penelitian tindakan (action research) cara ilmiah untuk mendapatkan data dengan tujuan dapat ditemukan masalah dan tindakan baru yang dapat digunakan untuk memecahkan masalah dikelas. PTK ini dilakukan dengan menerapkan model pembelajaran Aptitude Treatment Interaction (ATI) sebagai alternatif tindakan untuk meningkatkan hasil belajar geografi siswa kelas X IIS 2 SMA Negeri 8 Kendaripada materi pokok dinamika atmosfer dan dampaknya terhadap kehidupan.

\section{Tempat dan Waktu Penelitian}

Penelitian ini dilaksanakan di kelas X IIS 2 SMA Negeri 8 Kendari, yang beralamat di jalan
Garuda poros Moramo, kecamatan Abeli kota Kendari. Penelitian ini dilaksanakan pada Semester Genap Tahun Ajaran 2018/2019.

\section{Subjek Penelitian}

Subjek penelitian ini adalah siswa kelas X IIS 2 SMA Negeri 8 KendariSemester II (dua) Tahun Ajaran 2018/2019, yang berjumlah 25 orang terdiri dari 11 siswa laki-laki dan 14 siswa perempuan. Penetapan kelas X IIS 2sebagai subjek penelitian didasarkan pada observasi awal dimana nilai ratarata yang diperoleh masih rendah dan masih banyak siswa yang nilainnya belum mencapai Kriteria Ketuntasan Minimal (KKM) sebelum melakukan remedial.

\section{Teknik Analisis Data}

Data dalam penelitian ini dianalisis menggunakan deskripstifkualitatif dan kuantitatif. Analisis deskriptif kualitatif digunakan untuk memberikan penjelasan mengenai aktivitas siswa serta kemampuan guru selama proses pembelajaran berlangsung. Sedangkan analisis deskriptif kuantitatif digunakan untuk menyajikan presentase aktivitas guru dalam mengelola pembelajaran, presentase aktivitas siswa dan presentase ketuntasan hasil belajar siswa.

\section{a. Menentukan Hasil Belajar Siswa Secara Individual}

Dalam menentukan nilai hasil belajar siswa dapat menggunakan rumus:

$X i=\frac{S p i}{S m} x 100$

Keterangan:

$X \mathrm{i}=$ nilai yang diperoleh siswa ke-i

Spi = skor yang diperoleh siswa ke-i

$\mathrm{Sm}=$ skor maksimal (Usman Setiawati, 2001)

b. Menentukan Nilai Rata-Rata Hasil Belajar Siswa Dengan Rumus:

$\bar{X}=\frac{\sum X_{i}}{N}$

Keterangan:

$\bar{X} \quad=$ nilai rata - rata yang diperoleh siswa

$\sum \mathrm{Xi}=$ nilai yang diperoleh tiap siswa

$\mathrm{N} \quad=$ jumlah siswa secara keseluruhan

(Sudjana, 2002)

\section{c. Menentukan Tingkat Pencapaian Ketuntasan Belajar}

Presentase jumlah siswa yang hasil belajarnya sudah tuntas dapat menggunakan rumus sebagai berikut:

$\%$ Tuntas $=\frac{\sum T B}{N} \mathrm{X} 100 \%$

Keterangan:

$\sum_{\mathrm{TB}}=$ jumlah siswa yang tuntas belajar

$\mathrm{N}=$ jumlah siswa secara keseluruhan

(Sudjana, 2002) 


\section{d. Mengklasifikasikan Rata-Rata Skor Aktivitas Siswa}

$\begin{array}{ll}1 \leq \mathrm{Xi}<2 & \text { : Kategori Kurang } \\ 2 \leq \mathrm{Xi}<3 & \text { : Kategori Cukup } \\ 3 \leq \mathrm{Xi}<4 & \text { : Kategori Baik } \\ \mathrm{Xi}=4 & \text { : Kategori Sangat Baik }\end{array}$

(Susetyo, 2010)

Penjelasan kategori rata-rata aktivitas siswa adalah sebagai berikut:

a) Kategori sangat baik jika dalam satu kelompok terdapat lima sampai enam siswa atau semua siswa mampu menerapkan semua satuan aktivitas yang dinilai.

b) Kategori baik jika dalam satu kelompok terdapat satu sampai dua siswa yang kurang mampu menerapkan semua satuan aktivitas yang dinilai. c) Kategori cukup jika dalam satu kelompok terdapat tiga sampai empat siswa yang kurang mampu menerapkan semua satuan aktivitas yang dinilai.

d) Kategori kurang jika dalam satu kelompok terdapat lima sampai enam siswa yang kurang mampu menerapkan semua satuan aktivitas yang dinilai.

\section{HASIL PENELITIAN}

\section{Data Aktifitas Belajar Siswa Siklus I dan II}

Untuk mendapatkan gambaran rata-rata aktivitas belajar siswa selama pembelajaran pada siklus I pada pertemuan I dan II dapat dilihat pada gambar 1 sebagai berikut:

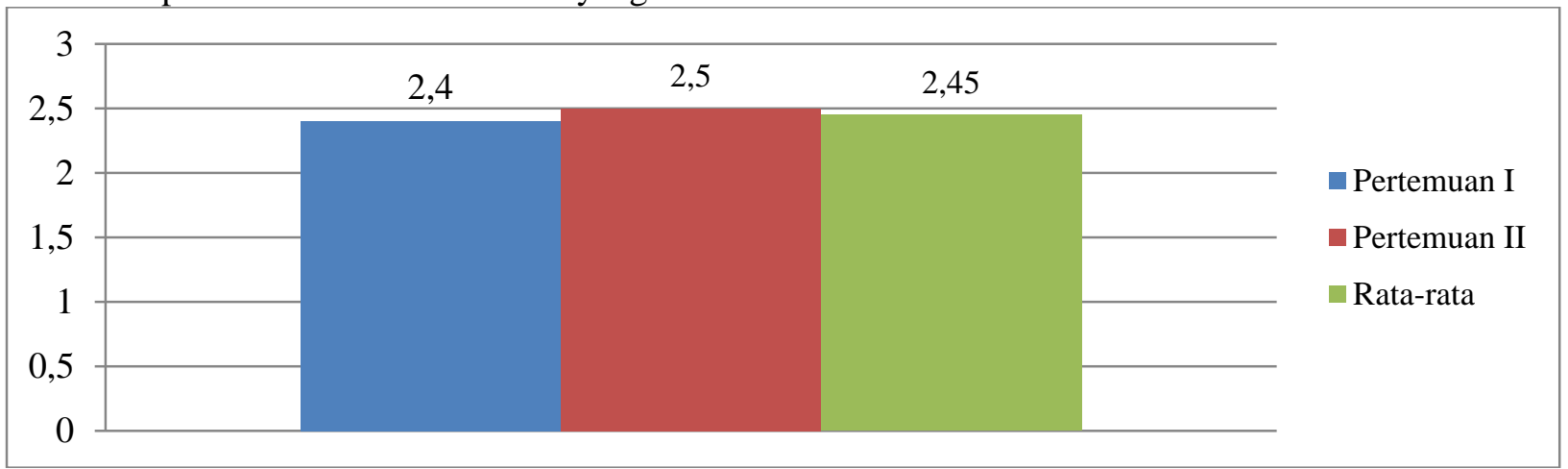

Gambar 1. Grafik Skor Rata-rata Aktivitas Belajar Siswa Siklus I (Analisis Data Primer, 2019).

Berdasarkan gambar 1 di atas tentang hasil observasi aktivitas belajar siswa dapat diperoleh gambaran bahwa hasil aktivitas belajar siswa tersebut masih belum memenuhi kriteria ketuntasan minimal yaitu 3,0, karena rata-rata aktivitas belajar siswa masih mencapai rata-rata 2,45 yang berkategori cukup. Dimana pada siklus I aktivitas siswa yang mendapat skor terendah dengan nilai rata-rata sebesar 2,1 adalah aktivitas belajar nomor 7 yaitu siswa mengerjakan latihan soal yang ada dalam LKS secara berkelompok, sedangkan aktivitas siswa yang mendapatkan skor tertinggi dengan nilai rata-rata sebesar 2,7 adalah aktivitas belajar nomor 3 yaitu siswa mendengarkan tujuan/kompetensi pembelajaran yang ingin dicapai.

Pada siklus II terlihat bahwa setiap aktivitas belajar yang dinilai telah mengalami peningkatan. Pada siklus ini, aktivitas belajar siswa yang mendapatkan skor terendah di siklus I yaitu 2,1 meningkat di siklus II menjadi 3,4 adalah aktivitas nomor 7 yaitu siswa mengerjakan latihan soal yang ada dalam LKS secara berkelompok. Sedangkan aktivitas belajar siswa yang mendapatkan skor tertinggi di siklus I dengan nilai rata-rata sebesar 2,7 meningkat di siklus II menjadi 3,3 adalah aktivitas belajar siswa nomor 3 yaitu siswa mendengarkan tujuan/kompetensi pembelajaran yang ingin dicapai. Pada siklus II dari 11 aspek aktivitas belajar siswa yang diobsevasi telah memperoleh nilai rata-rata yang terkategorikan baik, karena secara keseluruhan rata-rata aktivitas belajar siswa meningkat dari siklus I ke siklu II.

\section{Aktifitas Mengajar Guru Siklus I dan II}

Untuk mendapatkan gambaran rata-rata aktivitas guru selama pembelajaran pada siklus I pertemuan I dan II dapat dilihat pada gambar 2. 


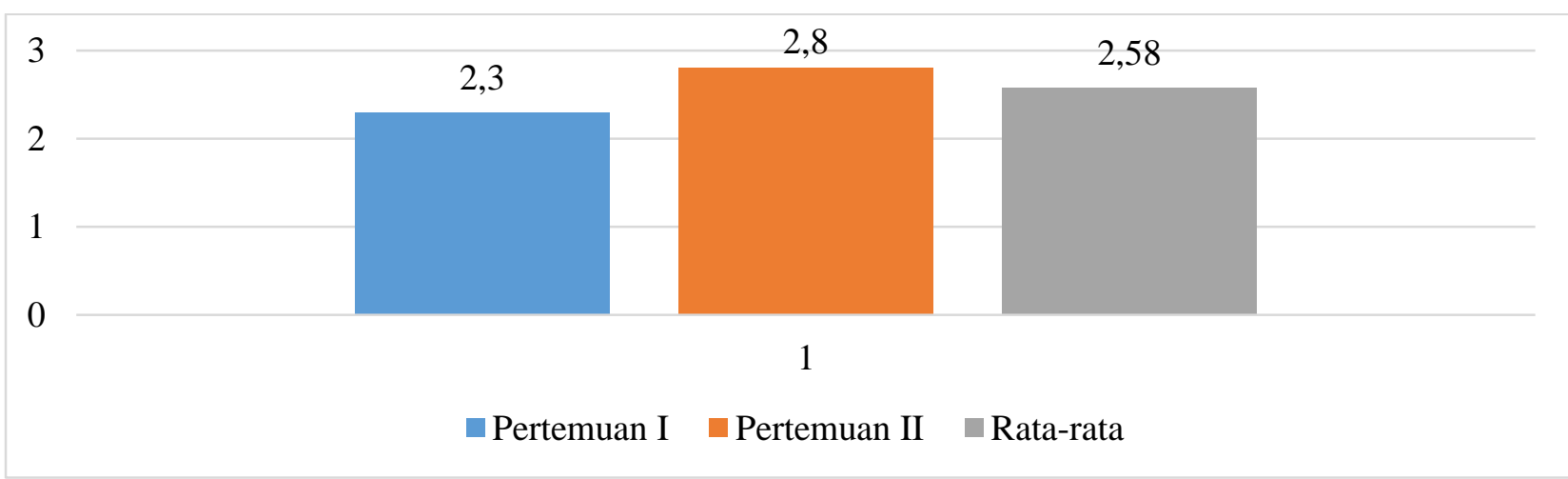

Gambar 2. Grafik Skor Rata-rata Aktivitas Guru Siklus I (Analisis Data Primer, 2019).

Berdasarkan gambar 2 diatas tentang hasil masing-masing kelompok, guru meminta setiap observasi aktivitas guru dapat diperoleh gambaran bahwa, hasil aktivitas guru tersebut masih belum memenuhi kriteria ketuntasan minimal yaitu 3,0, karena rata-rata aktivitas guru masih mencapai rata-rata 2,58 yang berkategorikan cukup. Dimana pada siklus I aktivitas guru yang mendapatkan skor terendah dengan nilai rata-rata sebesar 2 adalah aktivitas nomor 4,9 dan 16 yaitu guru memberi motivasi kepada siswa, guru membimbing kelompok (terutama kelompok yang memiliki kemampuan rendah) untuk menggunakan kemampuan berpikir dan konsentrasi saat mengerjakan soal LKS dalam diskusi, dan guru memberi tugas kepada siswa terkait dengan materi yang sudah dipelajari. Sedangkan aktivitas guru yang mendapatkan skor tertinggi dengan nilai rata-rata sebesar 3 adalah aktivitas nomor 1, 2, 5, 8, 12 dan 18 yaitu guru membuka pelajaran memberi salam dan doa sebelum memulai pelajaran, guru mengecek kehadiran siswa, guru menyampaikan tujuan pembelajaran, guru membagikan LKS kepada perwakilan kelompok untuk mempresentasikan laporan hasil akhir kelompoknya di depan kelas dan guru menutup kegiatan pembelajaran dengan salam. Aktivitas mengajar guru yang mendapatkan skor tertinggi pada siklus I dengan nilai rata-rata sebesar 3 pada siklus II meningkat menjadi 3,5 yaitu aktivitas nomor 5, 8 dan 12, sedangkan aktivitas nomor 1, 2 dan 18 meningkat menjadi 4. Pada siklus II dari 18 aspek aktivitas guru yang diobsevasi telah memperoleh nilai rata-rata yang terkategori baik, karena secara keseluruhan rata-rata aktivitas guru meningkat dari siklus I ke siklus II.

\section{Hasil Belajar Siswa Siklus I dan II}

Gambaran hasil belajar siswa kelas X IIS 2 yang diajar dengan menggunakan model pembelajaran ATI pada siklus II dapat dilihat pada gambar 3 sebagai berikut:

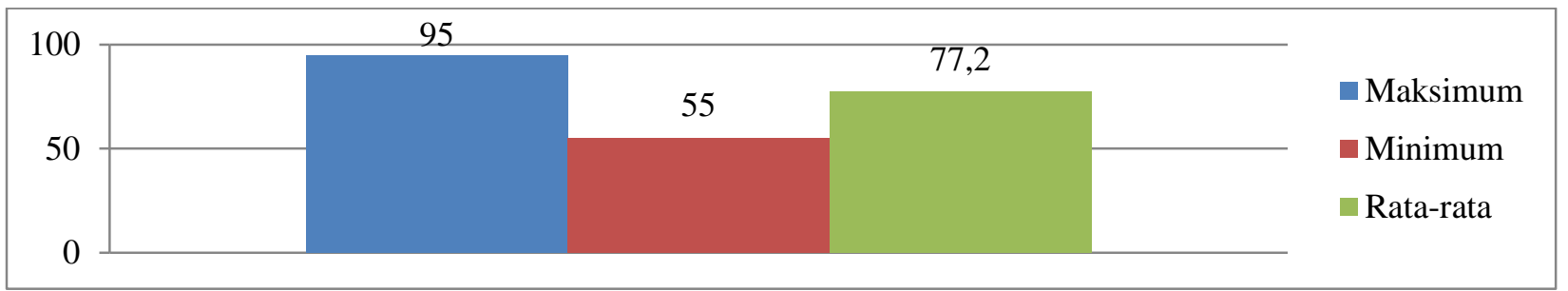

Gambar 3. Grafik Nilai Hasil Belajar Siklus II (Analisis Data Primer, 2019).

Selanjutnya berdasarkan analisis ketuntasan belajar siswa pada siklus II diperoleh hasil sebagaimana disajikan pada gambar 4 berikut:

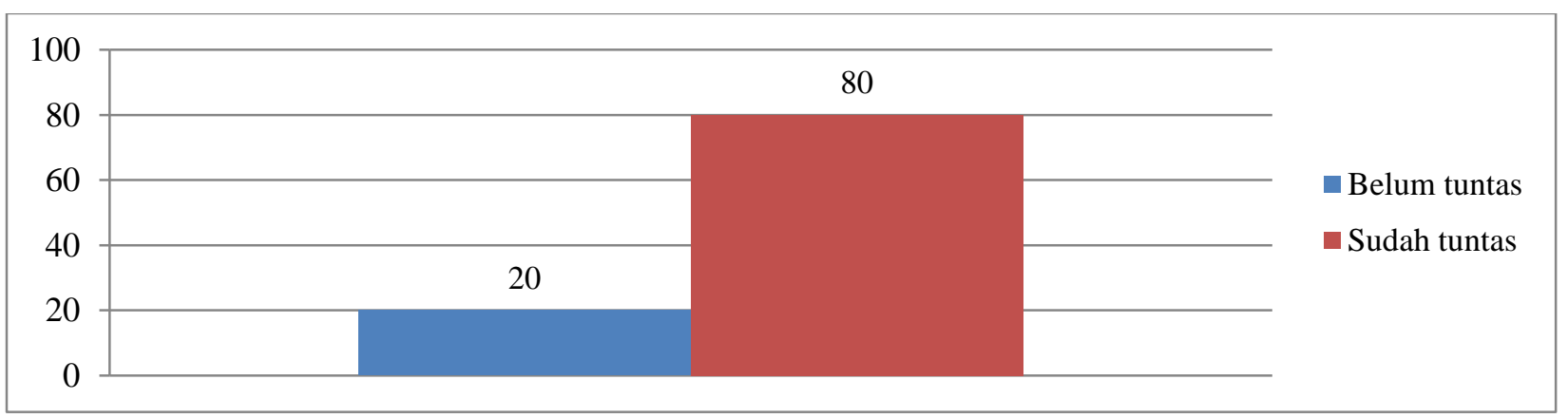

Gambar. 4. Grafik Presentase Ketuntasan Siswa Siklus II (Analisis Data Primer, 2019). 
Gambar 4 di atas menunjukkan bahwa ketuntasan belajar siswa pada siklus II yang memperoleh skor antara 0-69 berjumlah 5 orang dengan presentase $20 \%$, sedangkan siswa yang telah memperoleh skor antara 70-100 berjumlah 20 orang dengan presentase ketuntasan mencapai $80 \%$. Hasil ini sudah lebih baik jika dibandingkan dengan skor perolehan siswa pada siklus I. Dalam hal ini indikator ketuntasan belajar siswa telah tercapai atau berhasil, dimana secara klasikal yaitu jika nilai siswa yang telah mencapai KKM (70) adalah 80\%, maka dikatakan hasil penelitian telah tercapai dan berhasil.

\section{PEMBAHASAN}

\section{Aktivitas Belajar Siswa Selama Pembelajaran Berlangsung}

Berdasarkan permasalahan pertama tentang bagaimana gambaran aktivitas belajar siswa dalam proses belajar mengajar pada materi pokok atmofer yang diajar melalui penerapan model pembelajaran ATI, dapat dijelaskan berdasarkan hasil pengamatan pada setiap siklus baik siklus I maupun siklus II yang menunjukkan peningkatan kearah yang lebih baik. Peningkatan aktivitas belajar siswa tersebut menunjukkan adanya minat dan antusias siswa dalam mengikuti proses pembelajaran pada materi pokok atmofer dengan menggunakan model pembelajaran ATI.

Pada siklus I berdasarkan hasil analisis deskriptif terhadap aktivitas belajar siswa menunjukkan skor rata-rata aktivitas belajar siswa pada I sebesar 2,45 yang berkategori cukup. Pada siklus I ada beberapa aktivitas belajar siswa yang masih tergolong kurang dimana siswa belum terbiasa dengan model pembelajaran ATI diantaranya: (1) siswa memfokuskan pikiran pada satu pokok materi/bahasan yang ingin di bahas dan menjawab pertanyaan guru berada pada kategori cukup, (2) siswa mendengarkan tujuan/kompetensi pembelajaran yang ingin dicapai berada pada kategori cukup, (3) siswa menerima LKS dan mendiskusikan secara kelompok terkait soal yang disajikan dalam LKS berada pada kategori cukup, (4) siswa mengerjakan latihan soal yang ada dalam LKS secara berkelompok berada pada kategori cukup, (5) siswa bekerja sama menyimpulkan materi pembelajaran berada pada kategori cukup. Berdasarkan hasil refleksi pada siklus I ditemukan ada beberapa aktivitas siswa yang masih belum terlaksana dengan baik.Oleh karena itu dilakukan perbaikan pada siklus selanjutnya.

Pada siklus II dari hasil analisis deskriptif terhadap skor rata-rata aktivitas belajar siswa pada siklus tersebut menunjukkan adanya peningkatan yang signifikan dari aktivitas belajar siswa pada siklus I. Dimana skor rata-rata aktivitas belajar siswa pada siklus II sebesar 3,3 dengan kategori baik. Hal ini menunjukkan bahwa penelitian telah berhasil karena telah memenuhi standar minimal aktivitas belajar siswa yaitu 3,0 .

\section{Aktivitas Mengajar Guru Selama Pembelajaran Berlangsung}

Berdasarkan permasalahan kedua yaitu bagaimana gambaran aktivitas mengajar guru melalui penerapan model pembelajaran ATI dapat dijelaskan berdassarkan hasil pengamatan aktivitas mengajar guru pada setiap siklus baik pada siklus I maupun siklus II yang menunjukkan peningkatan ke arah yang lebih baik.

Pada siklus I berdasarkan analisa hasil refleksi, aktivitas guru menunjukkan skor rata-rata sebesar 2,58 yang berkategori cukup dimana aktivitas guru pada siklus I yang masih rendah diantaranya adalah (1) guru memberi motivasi kepada siswa berada pada kategori cukup, (2) guru membimbing kelompok (terutama kelompok yang memiliki kemampuan rendah) untuk menggunakan kemampuan berpikir dan konsentrasi saat mengerjakan soal LKS dalam diskusi berada pada kategori cukup, (3) guru meminta siswa untuk menghubungkan hasil dari pengamatannya dengan hasil materi diskusi berada pada kategori cukup, (4) guru meminta siswa untuk membuat kesimpulan dari hasil diskusi berada pada kategori cukup, (5) guru memberi tugas kepada siswa terkait dengan materi yang sudah dipelajari berada pada kategori cukup.

Berdasarkan hasil refleksi terhadap aktivitas guru, maka dengan mengetahui kekurangan-kekurangan pada siklus I, guru memperbaiki cara mengajarkan materi pembelajaran yang sesuai dengan model pembelajaran ATI. Sehingga diharapkan pada pertemuan selanjutnya diperoleh peningkatan aktivitas guru pada siklus selanjutnya.

Pada siklus II aktivitas mengajar guru menunjukkan peningkatan, dimana pada siklus II skor rata-rata aktivitas guru memperoleh nilai sebesar 3,4 yang berkategori baik. Hasil analisis dan pengamatan pada siklus tersebut menunjukkan adanya peningkatan aktivitas guru melalui penerapan model pembelajaran ATI. Hal tersebut menunjukkan bahwa penelitian telah berhasil karena memenuhi standar minimal aktivitas mengajar guru yaitu 3,0 .

\section{Hasil Belajar Siswa}

Berdasarkan hasil tes siklus pada siklus I diperoleh nilai minimum sebesar 50; nilai maksimum 90; rata-rata hasil belajar siswa sebesar 69,40. Secara klasikal dari 25 siswa yang mencapai persentase ketuntasan hasil belajar yaitu 15 siswa atau $60 \%$ yang mencapai nilai $\geq 70$ sesuai dengan nilai KKM

geografi yang ditetapkan di SMA Negeri 8 Kendari dan terdapat 10 orang siswa dengan persentasae sebesar $40 \%$ siswa yang nilainya belum mencapai KKM yang ditentukan di sekolah tersebut yaitu 70. Presentase ketuntasan pada siklus I ini belum mencapa target peneliti yaitu mencapai ketuntasan belajar secara klasikal minimal $80 \%$.

Studi lain yang dilakukan oleh Pertiwi (2017) menunjukkan bahwa diperoleh nilai rata-rata hasil 
belajar peserta didik adalah $83,36 \%$ dan ketuntasan belajar mencapai 82,10\%. Hasil tersebut menunjukkan bahwa pada siklus I secara klasikal peserta didik tuntas belajar, karena peserta didik yang memperoleh nilai sebesar 82,10. Ini lebih besar dari presentase ketuntasan yang dikehendaki yaitu sebesar $80 \%$. Adanya perbedaan hasil penelitian tersebut disebabkan dalam penerapan model pembelajaran ATI, peneliti menggambungkan siswa yang berkemampuan tinggi dalam kelas yang sama masing-masing siswa sesuai kemampuan siswa. Selain itu perbedaan materi juga yang diajarkan dalam pembelajaran sehingga terjadi perbedaan hasil penelitian pula. Karena dalam materi dinamika atmosfer cukup kompleks dan membutuhkan waktu yang banyak dalam membimbing siswa khususnya siswa yang berkemampuan rendah.

Berdasarkan refleksi dengan melihat aktivitasa siswa dan hasil belajar pada siklus I tersebut, dapat dengan siswa berkemampuan sedang dan rendah. Namun tetap memberikan perlakuan (treatment) yang berbeda kepada masing-masing siswa sesuai kemampuannya. Sedangkan studi yang dilakukan oleh Pertiwi (2017) membedakan siswa berkemampuan tinggi untuk belajar mandiri di luar kelas yang telah diberikan arahan sebelumnya dan untuk siswa berkemampuan sedang dan rendah diajar dalam ruang kelas yang sama. Namun tetap memberikan perlakuan yang berbeda kepada diambil suatu kesimpulan bahwa dalam proses pembelajaran tampak bahwa siswa kurang antusias. Hal tersebut ditunjukkan dengan kurangnya siswa dalam bertanya mengenai materi pembelajaran berada pada kategori cukup; siswa dalam mengerjakan LKS berada pada kategori cukup; siswa memperhatikan presentase teman-teman kelompoknya berda pada kategori cukup, dan siswa menyimak penguatan dan koreksi dari guru tentang hasil diskusi kelompok berada pada kategori cukup.

Tabel 3. Data Anlisis Ketuntasan Hasil Belajar Siswa Pada Siklus I

\begin{tabular}{cccc}
\hline Skor & Jumlah Siswa & Presentase & Ketuntasan Belajar \\
\hline $0-69$ & 10 orang & $40 \%$ & Belum Tuntas \\
$70-100$ & 15 orang & $60 \%$ & Sudah Tuntas \\
\hline Jumlah & 25 orang & $\mathbf{1 0 0 \%}$ & \\
\hline
\end{tabular}

Sumber: Analisis Data Primer, 2019.

Setelah melakukan analisis dan refleksi hasil belajar siswa pada siklus I, guru mata pelajaran dan peneliti mencoba melakukan perbaikan dalam proses belajar mengajar agar pada siklus selanjutnya siswa yang memenuhi ketuntasan belajar dapat meningkat seperti yang diharapkan. Pada siklus II berdasarkan hasil tes belajar siswa pada akhir siklus, terlihat bahwa hasil belajar siswa memperoleh nilai minimum 55; nilai maksimum 95; nilai rata-rata hasil belajar siswa sebesar 77,20. Dimana terdapat 20 orang siswa yang memperoleh nilai $\geq 70$ atau ketuntasan hasil belajar secara klasikal sebesar 80 $\%$ sedangkan jumlah siswa yang hasil belajarnya dibawah nilai KKM atau yang memperoleh nilai $<70$ sebanyak 5 orang atau $20 \%$ yang belum tuntas. Dari hasil tersebut menunjukkan peningkatan hasil belajar dari siklus I ke siklus II, walaupun masih ada 5 siswa yang belum mencapai ketuntasan belajar.

Pada siklus II ketuntasan belajar siswa telah tercapai yaitu $80 \%$ siswa telah tuntas dalam hasil

\section{KESIMPULAN}

Berdasarkan hasil dalam penelitian ini dapat ditarik kesimpulan sebagai berikut; gambaran aktivitas mengajar guru dengan menerapkan model pembelajaran Aptitude Treatment Interaction (ATI) pada setiap siklus meningkat. Aktivitas mengajar guru dengan belajar geografi. Berkaitan dengan hal tersebut maka peneliti menggangap telah berhasil mencapai targetnya. Dalam penelitian ini keberhasilan siswa ketika tes hasil belajar siklus II memberikan gambaran bahwa penerapan model ATi mampu meningkatkan hasil belajar geografi siswa. Hasil tersebut sejalan dengan penelitian Pertiwi (2017) yaitu terjadi peningkatan hasil belajar siswa dari siklus I ke siklus II, dimana diperoleh nilai rata-rata hasil belajar peserta didik adalah $83,36 \%$ dan ketuntasan belajar mencapai $78,94 \%$. Berdasarkan hal tersebut maka jawaban atas permasalahan penelitian telah terungkap yaitu pembelajaran melalui penerapan model pembelajaran ATI berhasil dalam meningkatkan aktifitas belajar siswa, aktifitas mengajar guru dan juga meningkatkan hasil belahar geografi kelas X IIS 2 SMA Negeri 8 Kendari khususnya pada materi pokok dinamika atmosfer dan dampaknya terhadap kehidupan.

menerapkan model pembelajaran ATI pada siklus I dengan rata-rata skor 2,58 termasuk kategori cukup dan pada siklus II mengalami peningkatan yaitu 3,4. Hasil belajar geografi siswa kelas X IIS 2 SMA Negeri 8 Kendari meningkat $20 \%$ setelah menerapkan model pembelajaran Aptitude Treatment Interaction (ATI) pada materi pokok 
dinamika atmosfer dan dampaknya terhadap kehidupan. Dimana pada siklus I yaitu diperoleh nilai terendah 50 , nilai tertinggi 90 , nilai rata-rata 69,40 serta ketuntasan belajar sebesar $60 \%$. Sedangkan pada siklus II nilai terendah 55, nilai tertinggi 95 , nilai rata-rata sebesar 77,20 dengan ketuntasan belajar $80 \%$ atau terdapat 20 dari 25 jumlah keseluruhan siswa memperoleh nilai $\geq 70$ sesuai KKM geografi yang ditentukan di SMA Negeri 8 Kendari.

\section{SARAN}

Berdasarkan kesimpulan di atas maka peneliti mengemukakan beberapa saran sebagai berikut; sebaiknya guru dapat menerapkan model pembelajaran Aptitude Treatment Interaction (ATI) pada pembelajaran geografi untuk mengatasi banyaknya siswa yang pasif dalam pembelajaran serta untuk meningkatkan hasil belajar geografi siswa pada mata pembelajaran geografi.

\section{UCAPAN TERIMA KASIH}

Ucapan terimakasih saya haturkan kepada pembimbing saya yaitu Drs. La Harudu sebagai pembimbing I dan La Ode Nursalam, S.Pd, M.Pd sebagai pembimbing II karena telah sabar dalam membantu dan membimbing proses penyelesaian tulisan ini. Selanjutnya ucapan terima kasih pula yang sebesar-besarnya kepada kedua orang tua karena telah mensuport, memfasilitasi serta memberikan bimbingan sehingga tulisan ini bisa selesai.

\section{DAFTAR PUSTAKA}

Ismayani, I. (2011). Penerapan Model Pembelajaran Aptitude Interaction (ATI) dalam Upaya Meningkatkan Kemampuan Pemecahan Masalah Matematis dan Motivasi Belajar Siswa. Jurnal Penelitian Tindakan Kelas (PTK). Vol. 6.

Nurdin, Syafrudin. (2005). Model Pembelajaran Yang Memperhatikan Keragaman Individu Siswa Dalam Kurikulum Berbasis Kompetensi. Jakarta: Quantum Teaching.

Pertiwi, Wiwit Candra. (2017). Penerapan Model Pembelajaran Aptitude Treatment Interaction (ATI) UntukMeningkatkan Hasil Belajar Peserta Didik Pada Pokok Bahasan Seni Rupa Dua Dimensi di Kelas XII MIPA 4 SMAN 2 Pekanbaru. Jurnal Penelitian Tindakan Kelas (PTK). Vol. 5.

Purwanto. (2011). Evaluasi Hasil Belajar. Pustaka Pelajar: Yogyakarta.

Sriyampriyati, dkk. (2011). Penerapan Model Pembelajaran Aptitude Treatment Interaction (ATI) untuk Meningkatkan Hasil Belajar Siswa pada Pokok Bahasan Reaksi Redoks di Kelas X SMAN 5 Pekanbaru. Jurnal Pendidikan Kimia FKIP Universitas Riau. Vol. 6

Sudjana. (2005). Metode Statistika. Bandung: Tarsito.

Susetyo, B. (2010). Statistka untuk Analisis Data Penelitian. Bandung: Refika Ditama.

Usman dan Setiawati. (2001). Statistika. Bandung: Remaja Rosdakarya. 
